\title{
Lack of association between the prothrombin rs1799963 polymorphism and juvenile myoclonic epilepsy
}

\author{
Ausência de associação entre o polimorfismo G20210A (rs1799963) da protrombina e \\ epilepsia mioclônica juvenil
}

João Paulo Lopes Born¹, Bruna Priscila dos Santos ${ }^{1}$, Rodrigo Secolin², Fernando Tenório Gameleira ${ }^{3}$, Tiago

Gomes de Andrade ${ }^{3}$, Luciana Cláudia Herculano Machado ${ }^{4}$, Livia Leite Góes Gitaî5, Daniel Leite Góes Gitai ${ }^{6}$

\begin{abstract}
Juvenile myoclonic epilepsy (JME) accounts for $26 \%$ of generalized idiopathic epileptic syndromes. The highest levels of thrombin activity are closely involved in the development of neurological diseases, including epilepsy. The prothrombin c.20210G>A (rs1799963) variation, which alters prothrombin mRNA stability, is associated with high plasma prothrombin levels. Objective: The present study was designed to investigate whether the SNP rs1799963 is a risk factor for JME in the northeastern Brazilian population. Results: The polymorphism was genotyped in 207 controls and 123 patients using polymerase chain reaction-restriction fragment length polymorphism method. No significant differences were observed in the genotype and allele frequencies of this polymorphism between cases and controls. Conclusion: These results present no evidence for an association of rs 1799963 with JME. Further studies including other types of epilepsy are required to investigate the involvement of prothrombin gene in the genetic susceptibility to chronic seizure.
\end{abstract}

Keywords: polymorphism, prothrombin, juvenile myoclonic epilepsy.

\section{RESUMO}

Epilepsia mioclônica juvenil (EMJ) representa 26\% das síndromes epilépticas idiopáticas generalizadas. Níveis elevados de atividade da trombina estão intimamente envolvidos no desenvolvimento de distúrbios neurológicos, incluindo epilepsia. A variante c.20210G>A (rs1799963) do gene de protrombina, que altera a estabilidade do RNAm, está associada com altos níveis de protrombina no plasma. Objetivo: Investigar se o SNP rs1799963 é um fator de risco para EMJ em uma amostra da população do nordeste brasileiro. Resultados: O polimorfismo foi genotipado em 123 pacientes e 207 controles usando a reação de polimerase em cadeia com restrição de polimorfismo. Não observamos diferença significativa nas frequências alélicas e genotípicas deste polimorfismo, entre as populações de pacientes e controle. Conclusão: Estes resultados não demonstram evidências para uma associação do polimorfismo rs1799963 com EMJ. Estudos posteriores, incluindo outros tipos de epilepsia, são necessários para investigar o envolvimento do gene protrombina na susceptibilidade genética a crises crônicas.

Palavras-chave: polimorfismo, protrombina, epilepsia mioclônica juvenil.

Juvenile myoclonic epilepsy (JME) is a subtype of common idiopathic generalized epilepsy (IGE) and accounts for $10 \%$ of all forms of epilepsy and up to $26 \%$ of IGE. Onset is at puberty with equal sex ratio and it is characterized by myoclonic jerks, occasional generalized tonic-clonic seizures, and sometimes absence seizures $^{1}$. It is also highly drug-dependent, since a

'Universidade Federal de Alagoas, Instituto de Ciências Biológicas e da Saúde, Maceió AL, Brazil;

²Universidade de Campinas, Departamento de Genética Médica, Campinas SP, Brazil;

${ }^{3}$ Universidade Federal de Alagoas, Arapiraca AL, Brazil;

«Universidade Federal de Alagoas, Instituto de Ciências Biológicas e da Saúde, Departamento de Histologia, Maceió AL, Brazil;

EUniversidade Federal de Alagoas, Faculdade de Medicina, Maceió AL, Brazil;

${ }^{6}$ Universidade Federal de Alagoas, Instituto de Ciências Biológicas e da Saúde, Departamento de Biologia Celular Molecular e Genética, Maceió AL, Brazil.

Correspondence: Daniel L. G. Gitai; Av. Lourival Melo Mota, s/n, Cidade Universitária, Universidade Federal de Alagoas, Instituto de Ciências Biológicas e da Saúde; 57072-900 Maceió AL, Brasil; E-mail: danielgitai@gmail.com

The study was produced in Department of Cell, Molecular Biology and Genetic, Institute of Biological Sciences and Health, Federal University of Alagoas, Maceió, Alagoas, Brazil.

Conflict of interest: There is no conflict of interest to declare.

Support: Brazilian Agencies FAPEAL grant \#60030-692/2009 and CNPq. JPLB and DHA received fellowships from FAPEAL. TGA is a CNPq research fellow. Received 14 October 2013; Received in final form 08 November 2014; Accepted 28 November 2014. 
frequent recurrence is reported after antiepileptic drugs (AED) discontinuation 2 . Genetic factors are known to play an important role in the etiology of JME. Despite the existence of rare mutations responsible for some familial forms inherited in a mendelian pattern, the genetics of JME is complex and probably reflect the simultaneous involvement of multiple genes with minor effect and environmental factors ${ }^{3}$. The identification of these susceptibility genes is a great challenge ${ }^{4}$. For this purpose, an experimental approach that has been widely used is genetic association studies directed to candidate genes selected according to their molecular function.

Evidences support a role for serine proteases in the sequence of events that can lead to neuropathological situations ${ }^{5}$. Thrombin, a serine protease essential in the coagulation cascade is involved in the production of seizures ${ }^{6}$. It was demonstrated that active thrombin injected into rat brains resulted in both electrographic and clinical seizures ${ }^{7}$. It was proposed that thrombin, acting on its receptor, protease-activated receptor 1 (PAR1), has marked effects on the production of long-term potentiation (LTP) in responses to afferent stimulation and that it enhances the sensitivity to epileptic seizures in brain slices ${ }^{6}$. Thrombin may triggers the generation of epileptic seizures by reducing the inhibitory and increasing the excitatory tone in CA3 neurons ${ }^{5,8,9}$. The brain can be exposed to thrombin as a result of increased permeability of the blood-brain barrier that takes place during severe epilepsy. Moreover, at a brain with a intact BBB as supposed for idiophatic epilepsy, thrombin can be generated locally from prothrombin which was shown to be expressed in rat and human brains ${ }^{10,11}$. In support of this, patients with neurological disorders present the levels of local prothrombin, thrombin and PAR1 increased on astrocytes and neurons ${ }^{12}$.

The SNP rs 1799963 leads to the c.20210G>A variation in the 3 '-UTR region of prothrombin gene, which is a bifunctional polymorphism that alters prothrombin mRNA stability and processing ${ }^{13}$. Three-fold more prothrombin protein and mRNA were produced in NIH-3T3 cells transfected with the prothrombin cDNAs containing the rs $1799963^{*} \mathrm{~A}$ allele compared to cells with $\operatorname{rs} 1799963^{*} \mathrm{G}^{13}$. In fact, this polymorphism is associated with high plasma prothrombin levels and with an increased risk of thrombosis and other disease conditions ${ }^{14,15}$. These physiological attributes make the protrombin an interesting candidate gene for investigation in an IGE syndrome such as JME. Through this case/ control design, we intended to investigate whether SNP rs1799963 show association with JME in one northeastern Brazilian population.

\section{METHOD}

\section{Patients and controls}

This study included 123 unrelated Brazilian patients with JME and 207 normal control subjects. The study was approved by the Ethics Committee of the Federal University of Alagoas, Brazil (no. 0900-2005-11). The subjects signed informed consent before blood tests were performed. Cases were matched with controls according to age, sex, ethnicity, and geographic location of origin. Individuals with a history of epileptic seizures or neuropsychiatric disorders were excluded from the control sample. All patients were recruited from the state of Alagoas in northeastern Brazil. The probands were unambiguously diagnosed cases of JME with classification based on the published criteria of the Commission on Classification and Terminology of the International League Against Epilepsy ${ }^{16}$. All patients were submitted to electroencephalography analysis and only those with generalized spike wave were included in this study.

\section{Genetic analysis}

The SNP rs 1799963 was detected by the use of the protocols described by Kruse et al. ${ }^{17}$, with modification. Briefly, DNA was extracted from peripheral blood leucocytes using FlexiGene DNA Kit (Qiagen). A total of 50 ng of genomic DNA was mixed with 5 pmol of each polymerase chain reaction (PCR) primer in a total volume of $25 \mu \mathrm{L}$ containing $10 \mathrm{mM}$ Tris-hydrochloride, pH 8.8; 50 mM potassium chloride; $0.8 \%$ Nonidet P40; $1.5 \mathrm{mM}$ magnesiumchloride; $0.2 \mathrm{mMeach}$ deoxyribonucleotidetriphosphate; and 0.5 of DNA polymerase (Fermentas Life Sciences). Following primers: 5 ` CAATAAAAGTGACTCTCATC 3’ (forward, underlined $\mathrm{T}$ indicates change to create TaqI site) and 5' AGGTGGTGGATTCTTAAGTC 3` (reverse) were used to obtain PCR products of 118 bp size (Gene-Bank accession no. ref(NT_009237.18). The reaction mixture was cycled as follows in a DNA thermal cycler (BioCycler, MJ96G model): inicial denaturation step at $94^{\circ} \mathrm{C}$ for $3 \mathrm{~min}, 35$ cycles at $94^{\circ} \mathrm{C}$ for $1 \mathrm{~min}$, $55^{\circ} \mathrm{C}$ for $1 \mathrm{~min}$ and $72^{\circ} \mathrm{C}$ for $1 \mathrm{~min}$, and a final extension at $72^{\circ} \mathrm{C}$ for 7 min. A $12 \mu \mathrm{L}$ aliquot of the amplicon was then submitted to restriction reaction at $65^{\circ} \mathrm{C}$ for $6 \mathrm{~h}$ with Taq I Restriction Enzyme (New England Biolabs, UK; cat. no. R0149L). Digestion products were separated by electrophoresis on $2.5 \%$ agarose gels and were visualized by ultraviolet light after staining with ethidium bromide. In this assay, the rs $1799963^{*} \mathrm{G}$ allele was digested, whereas the rs $1799963^{*} \mathrm{~A}$ was not. Digestion of the wild-type PCR product gave a fragment of $98 \mathrm{bp}$, and digestion of the variant PCR product gave a fragment of $118 \mathrm{bp}$.

\section{Statistical analysis}

All descriptive and statistical analysis was performed using SNPStats ${ }^{18}$. Allele and genotype frequencies were calculated by counting and Hardy-Weinberg equilibrium was estimated using Chi-square test. Genetic association analysis was performed using logistic regression analysis, including odds ratio (OR) with the $95 \%$ confidence interval $(95 \% \mathrm{CI})$. We then estimated the OR adjusted by those clinical variables that were selected in the general linear model analysis with a logistic regression stepwise procedure. The selected clinical variables evaluated were sex, pharmacological treatment and type of seizure. A priori statistical power analysis 
was performed by GPOWER 3.1.7 software $^{19}$ using the following parameters: logistic regression test; two-tail; $\mathrm{OR}=1.5$; nominal significance level $\alpha=0.05 ; \mathrm{n}=330$.

\section{RESULTS}

The mean age at onset of the JME probands was 13 years (standard deviation $(\mathrm{SD})=4.0$ ), of which $65 \%$ were females. The triad of myoclonus, absences, and generalized tonicclonic seizures was observed in $41 \%$, the combination of myoclonus and generalized tonic-clonic seizures in 50\%, the combination of myoclonus and absence was observed in $8 \%$, and the myoclonus alone in $1 \%$ of patients. Of the patients, $58 \%$ were receiving monotherapy treatment with sodium valproate, $7 \%$ with Phenobarbital and $5 \%$ with lamotrigine, carbamazepine or fenitoine. The other $30 \%$ of patients were receiving polytherapy treatment. The populations studied had the following ethnic distribution: among patients $23 \%$ were Caucasians, $73.7 \%$ were Mulatto and 3.3\% were African descent; among controls $30.3 \%$ were Caucasians, $62.2 \%$ were Mulatto and $7.5 \%$ were of African descent.

The genotype distribution did not deviate significantly from that expected by Hardy-Weinberg equilibrium $(\mathrm{p}=1.0$ ). Duplicated genotyping of $20 \%$ of samples revealed $100 \%$ of genotyping concordance. According Table, the proportions of rs $1799963 \% \mathrm{GG}$ and rs $1799963 \mathrm{GA}$ were $97.6 \%$ and $2.4 \%$ in JME patients, and $97.6 \%$ and $2.4 \%$ in control group, respectively. None individual was genotyped as rs $1799963^{*} \mathrm{AA}$. The allele frequencies of $\mathrm{rs} 1799963^{*} \mathrm{G}$ and $\mathrm{rs} 1799963^{*} \mathrm{~A}$ were $99 \%$ and $1 \%$ in JME patients, and $99 \%$ and $1 \%$ in control group, respectively. Logistic regression results did not showed significant association signal between rs1799963 and JME phenotype ( $p=0.99)$ even when odds ratio was adjusted by clinical variables (data not shown). This study showed a statistical power of $82.81 \%$ to detect association of SNP rs1799963 as susceptibility for JME.

\section{DISCUSSION}

To our knowledge this is the first association study between the SNP rs1799963 of the prothrombin gene and epilepsy. Patients with JME, the most common subtype of idiopathic generalized epilepsy which presents a strong influence of the genetic component, were selected. We studied rs1799963 in JME because it has been functionally related to altered levels of products (RNA and proteins) of the prothrombin gene and thrombin protein ${ }^{13,14}$. The highest levels of thrombin activity are closely involved in the development of neurological diseases, including epilepsy ${ }^{9}$. However, our data did not show a significant difference in the genotype and allele frequencies of this polymorphism between cases and controls, suggesting that there is no association of rs1799963 with JME in this Brazilian sample.
Table. Genotype frequencies of G20210A polymorphism in the controls and JME patients.

\begin{tabular}{lcccc}
\hline Genotype & Control (207) & JME (123) & OR (95\% Cl) & p-value \\
\hline GG & 202 & 120 & 1.00 & 0.99 \\
GA & 5 & 3 & $1.01(0.24-4.30)$ & \\
\hline The p-values were calculated from logistic regression analysis adjusting ethnicity \\
and sex.JME:Juvenile myoclonic epilepsy; OR: Odds ratio; Cl:Confidence interval.
\end{tabular}

Although the sample size used in this analysis, statistical power showed that this sample is enough to detect association with JME Additionaly, our study included only the patients with JME rather than analyzing a clinically heterogeneous population with several epilepsy syndromes. This approach might have minimized possible bias from the limited sample size, which is a common problem in genetic association studies ${ }^{20,21}$. However, replication studies in independent sample are needed in order to strength our findings.

Our data also contributes to the investigation of the frequency of rs1799963 polymorphism in Brazilian population. Considering the general population, including both patient and control individuals, the prevalence of heterozygous carriers were $0.6 \%$ and $1.8 \%$ among Caucasian and Mulatto individuals, respectively. The mutant allele rs1799963*A was not detected in Afro-descendants individuals. These findings are in agreement with other reports showing that the prothrombin polymorphism varies among different ethnic groups, presenting a very low frequency in Afro-descendants $(0.3 \%)^{22}$.

The frequencies of genotypes ( $98 \%$ for rs $1799963 * \mathrm{GG}$ and $2 \%$ for rs $1799963 * \mathrm{GA}$ ) and alleles (99\% for $\mathrm{rs} 1799963^{*} \mathrm{G}$ and $1 \%$

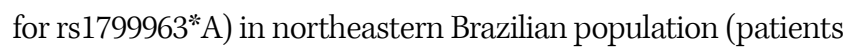
and control) observed in this study are consistent with results in other Brazilian subpopulations reported in previous studies. In fact, in general Brazilian population the mutant allele frequency ranged between 0.7\%-3.6\% (rs1799963*A) ${ }^{23,24,25}$. Brazilian population has an extremely heterogeneous ethnic composition, unevenly distributed across the country with variable degrees of admixtures ${ }^{25}$. This heterogeneity may also explain the allele frequency spectrum observed when different reports are considered. Various studies showed that the carrier frequency of the prothrombin rs1799963 is different among populations who immigrated to Brazil. In healthy Southern Europeans it was around $3 \%{ }^{26}$, nearly twice as high as the data obtained from Northern European populations ${ }^{27,28}$. In contrast, rs1799963 was found to be rare in African Americans and totally absent among Japanese and Koreans ${ }^{29,30}$. Knowing the frequency of prothrombin polymorphism in Brazilian miscigenated population and subgroups may have clinical and epidemiological implications.

\section{ACKNOWLEDGMENTS}

The authors thank all the individuals who participated in the study and the Neurology care unit team of Professor Alberto Antunes Hospital/Federal University of Alagoas. 
1. Janz D. Epilepsy with impulsive petit mal (juvenile myoclonic epilepsy). Acta Neurol Scand. 1985;72(5):449-59. http://dx.doi.org/10.1111/j.1600-0404.1985.tb00900.x

2. Beghi E. AED discontinuation may not be dangerous in seizure-free patients. J Neural Transm. 2011;118(2):187-91. http://dx.doi.org/10.1007/s00702-010-0528-y

3. Gardiner M. Genetics of idiopathic generalized epilepsies. Epilepsia. 2005;46(suppl s9):15-20. http://dx.doi.org/10.1111/j.1528-1167.2005.00310.x

4. Gitai DL, Romcy-Pereira RN, Gitai LL, Leite JP, GarciaCairasco N, Paco-Larson ML. Genes e epilepsia I: epilepsia e alterações genéticas. Rev Assoc Med Bras. 2008;54(3):272-8. http://dx.doi.org/10.1590/S0104-42302008000300023

5. Gingrich MB, Traynelis SF. Serine proteases and brain damage - is there a link? Trends Neurosci. 2000;23(9):399-407. http://dx.doi.org/10.1016/S0166-2236(00)01617-9

6. Maggio N, Shavit E, Chapman J, Segal M. Thrombin induces long-term potentiation of reactivity to afferent stimulation and facilitates epileptic seizures in rat hippocampal slices: toward understanding the functional consequences of cerebrovascular insults. J Neurosci. 2008;28(3):732-6. http://dx.doi.org/10.1523/JNEUROSCI.3665-07.2008

7. Lee KR, Drury I, Vitarbo E, Hoff JT. Seizures induced by intracerebral injection of thrombin: a model of intracerebral hemorrhage. J Neurosurg. 1997;87(1):73-8. http://dx.doi.org/10.3171/jns.1997.87.1.0073

8. Isaeva E, Hernan A, Isaev D, Holmes GL. Thrombin facilitates seizures through activation of persistent sodium current. Ann Neurol. 2012;72(2):192-8. http://dx.doi.org/10.1002/ana.23587

9. Maggio N, Cavaliere C, Papa M, Blatt I, Chapman J, Segal M. Thrombin regulation of synaptic transmission: implications for seizure onset. Neurobiol Dis. 2013;50:171-8. http://dx.doi.org/10.1016/j.nbd.2012.10.017

10. Arai T, Miklossy J, Klegeris A, Guo JP, McGeer PL. Thrombin and prothrombin are expressed by neurons and glial cells and accumulate in neurofibrillary tangles in Alzheimer disease brain.J Neuropathol Exp Neurol. 2006;65(1):19-25. http://dx.doi.org/10.1097/01.jnen.0000196133.74087.cb

11. Boven LA, Vergnolle N, Henry SD, Silva C, Imai Y, Holden J, et al. Up-regulation of proteinase-activated receptor 1 expression in astrocytes during HIV encephalitis. J Immunol. 2003;170(5):2638-46. http://dx.doi.org/10.4049/jimmunol.170.5.2638

12. Sokolova E, Reiser G. Prothrombin/thrombin and the thrombin receptors PAR- 1 and PAR- 4 in the brain: localization, expression and participation in neurodegenerative diseases. Thromb Haemost. 2008;100(4):576-81. http://dx.doi.org/10.1160/TH08-03-0131

13. Carter AM, Sachchithananthan M, Stasinopoulos S, Maurer F, Medcalf RL. Prothrombin G20210A is a bifunctional gene polymorphism. Thromb Haemost. 2002;87(5):846-53.

14. Poort SR, Rosendaal FR, Reitsma PH, Bertina RM. A common genetic variation in the 3'-untranslated region of the prothrombin gene is associated with elevated plasma prothrombin levels and an increase in venous thrombosis. Blood. 1996;88(10):3698-703.

15. Favaretto E, Sartori M, Conti E, Legnani C, Palareti G. G1691A factor $V$ and G20210A FII mutations, acute ischemic stroke of unknown cause, and patent foramen ovale. Thromb Res. 2012;130(5):720-4. http://dx.doi.org/10.1016/j.thromres.2012.07.020

16. Commission on Classification and Terminology of the International League Against Epilepsy. Proposal for revised classification of epilepsies and epileptic syndromes. Epilepsia. 1989;30(4):389-99. http://dx.doi.org/10.1111/j.1528-1157.1989.tb05316.x
17. Kruse L, Mitchell AM, Camargo CA Jr, Hernandez J, Kline JA. Frequency of thrombophilia-related genetic variations in patients with idiopathic pulmonary embolism in an urban emergency department. Clin Chem. 2006;52(6):1026-32. http://dx.doi.org/10.1373/clinchem.2005.061861

18. SoléX, Guinó E, Valls J, Iniesta R, Moreno V. SNPStats: a web tool for the analysis of association studies. Bioinformatics. 2006;22(15):1928-9. http://dx.doi.org/10.1093/bioinformatics/btl268

19. Faul F, Erdfelder E, Buchner A, Lang AG. Statistical power analyses using G*Power 3.1: tests for correlation and regression analyses. Behav Res Methods. 2009;41(4):1149-60. http://dx.doi.org/10.3758/ BRM.41.4.1149

20. Greenberg DA, Subaran R. Blinders, phenotype, and fashionable genetic analysis: a critical examination of the current state of epilepsy genetic studies. Epilepsia. 2011;52(1):1-9. http://dx.doi.org/10.1111/j.1528-1167.2010.02734.x

21. Santos B, Marques T, Malta M, Gameleira F, Secolin R, Andrade Tet al. PER2 rs2304672, CLOCK rs1801260, and PER3 rs57875989 polymorphisms are not associated with juvenile myoclonic epilepsy. Epilepsy Behav. 2014;36:82-5. http://dx.doi.org/10.1016/j.yebeh.2014.04.024

22. Segal JB, Brotman DJ, Necochea AJ, Emadi A, Samal L, Wilson $L M$, et al. Predictive value of factor $V$ Leiden and prothrombin G20210A in adults with venous thromboembolism and in family members of those with a mutation: a systematic review. JAMA. 2009;301 (23):2472-85. http://dx.doi.org/10.1001/jama.2009.853

23. Andrade FL, Annichino-Bizzacchi JM, Saad ST, Costa FF, Arruda VR. Prothrombin mutant, factor V Leiden, and thermolabile variant of methylenetetrahydrofolate reductase among patients with sickle cell disease in Brazil. Am J Hematol. 1998;59(1):46-50. http://dx.doi.org/10.1002/(SICl)1096-8652(199809)59:1<46::AIDAJH9>3.0.CO;2-\#

24. Couto FD, Boas WV, Lyra I, Zanette A, Dupuit MF, Almeida MN et al. A C677T methylenetetrahydrofolate reductase (MTHFR) polymorphism and G20210A mutation in the prothrombin gene of sickle cell anemia patients from Northeast Brazil. Hemoglobin. 2004;28(3):237-41. http://dx.doi.org/10.1081/HEM-120040308

25. Silva Filho IL, Leite AC, Moura PG, Ribeiro GS, Cavalcante AC, Azevedo FC et al. Genetic polymorphisms and cerebrovascular disease in children with sickle cell anemia from Rio de Janeiro, Brazil. Arq Neuropsiquiatr. 2011;69(3):431-5. http://dx.doi.org/10.1590/S0004-282X2011000400004

26. Rosendaal FR, Doggen CJ, Zivelin A, Arruda VR, Aiach M, Siscovick DS, et al. Geographic distribution of the $20210 \mathrm{G}$ to A prothrombin variant. Thromb Haemost. 1998;79(4):706-8.

27. Cumming AM, Keeney S, Salden A, Bhavnani M, Shwe KH, Hay CR. The prothrombin gene G20210A variant: prevalence in a U.K. anticoagulant clinic population. Br J Haematol. 1997;98(2):353-5. http://dx.doi.org/10.1046/j.1365-2141.1997.2353052.x

28. Hillarp A, Zöller B, Svensson PJ, Dahlbäck B. The 20210 A allele of the prothrombin gene is a common risk factor among Swedish outpatients with verified deep venous thrombosis. Thromb Haemost. 1997;78(3):990-2.

29. Hessner MJ, Luhm RA, Pearson SL, Endean DJ, Friedman KD, Montgomery RR. Prevalence of prothrombin G20210A, factor $V$ G1691A (Leiden), and methylenetetrahydrofolate reductase (MTHFR) C677T in seven different populations determined by multiplex allele-specific PCR. Thromb Haemost. 1999;81(5):733-8.

30. Isshiki I, Murata M, Watanabe R, Matsubara Y, Kawano K, Aoki N et al. Frequencies of prothrombin 20210 G-->A mutation may be different among races--studies on Japanese populations with various forms of thrombotic disorders and healthy subjects. Blood Coagul Fibrinolysis. 1998;9(1):105-6.http://dx.doi.org/10.1097/00001721-199801000-00014 